\title{
Post Covid-19 Hiponatremi Olgusu ve Literatürün Gözden Geçirilmesi
}

A Case of Post Covid-19 Hyponatremiaand Review of theLiterature

${ }^{1}$ Eskișehir Osmangazi Üniversitesi Tip Fakültesi İç Hastalıkları Anabilim Dalı, Eskişehir, Türkiye

${ }^{2}$ Eskișehir Osmangazi Üniversitesi Tip Fakültesi İç Hastalıkları Anabilim Dalı, Genel Dahiliye Bilim Dalı, Eskişehir,

Türkiye

\section{Özet}

2019 yllı aralık ayında başlayan Covid 19 enfeksiyonu, dünya genelindeki yaygınlığı, akut ve kronik dönem etkileri, artmış morbiditevemortalitesi nedeniyle günümüzde de önemini korumaktadır. Seyri sırasında klinikte en sık gözlenen elektrolit bozukluğu olarak hiponatremi dikkat çekmektedir. Literatürde hiponatremininCovid 19 enfeksiyonunda kötü prognostik sonuçlarla ilișkisi tartışılmaktadır. Biz de kliniğimizde Covid 19 enfeksiyonu sonrası erken dönemde şikayetleri devam eden, yapılan tetkiklerinde hiponatremi saptanan, adrenal yetmezlik ve hipofizermakroadenom tanısına ulaşılan bir olguyu sunmak istedik. Bu olguyla birlikte Covid 19 ve hiponatremi ilişkisi de tartı̧ılmaya çalışılacaktır.

Anahtar Kelimeler: Covid 19 enfeksiyonu, Hiponatremi, Uygunsuz ADH sendromu
Correspondence:

Pinar YILDIZ

Eskişehir Osmangazi Üniversitesi

Tip Fakültesi İç Hastalıkları Anabilim

Dalı, Genel Dahiliye Bilim Dal,

Eskişehir, Türkiye

e-mail: pinaresogu@gmail.com
${ }^{1}$ Selin Meşeli, ${ }^{2}$ Pınar Yıldız

\begin{abstract}
Anahtar Kelimeler: Covid 19 enfeksiyonu, Hiponatremi, Uygunsuz ADH sendromu
\end{abstract}
\section{Abstract}

Covid 19 infection, whichstarted in December 2019, maintainsitsimportancetodayduetoitsworldwideprevalence, acuteandchroniceffects, increasedmorbidityandmortality. Duringitscourse, hyponatremia is themostcommonelectrolytedisorderobserved in theclinic. Therelationshipbetweenhyponatremiaandpoorprognosticoutcomes in Covid 19 infection is discussed in theliterature. Wepresent a case in theclinic, in thecase of Covid 19, whoseclinicalexaminationsarestillongoingandhyponatremiamacroadenomawasdiagnosed in theexaminations. Withthiscase, therelationshipbetweenCovid 19 andhyponatremiawillalso be discussed.

Keywords: Covid 19 infection, Hyponatremia, InappropriateAntidiüretiksyndrome 


\section{Giriș}

Aralık 2019'da Çin'in Wuhan şehrinde başlayan, Mart 2020'de Dünya Sağlık Örgütü (DSÖ) tarafindan pandemi olarak kabul edilen Covid 19 hastalığ1 SARS-COV2 tarafindan oluşmaktadır. Kliniği asemptomatikten, ağır solunum yetmezliği sendromuna kadar geniş bir spektrumda görülmektedir $(1,2)$. Covid 19 hastalığında; baş ağrısı, boğaz ağrısı, karın ağrıs1, eklem ağrıları, ateş, öksürük, nefes darlığı, bulantı, kusma, ishal, tat ve koku kaybı gibi çok farklı semptomlar görülebilir. Hastalığın akut enfeksiyonu uzayabilmekte ve post covid dönemi denilen uzamış bir etkiden bahsedilmektedir. Covid 19 enfeksiyonu sonrası semptom ve bulguların on iki haftadan daha uzun sürmesi ve bu durumu açıklayacak başka nedenlerin dışlanması halinde post covid sendromu tanisi konulmaktadır (3). 50 yaş üzerinde, ağır Covid 19 enfeksiyonu olan kişilerde görülme ihtimali yüksek olan bu sendromun; yetersiz antikor yanıtı, uzamış etki, persistan inflamatuar yanıt nedenli gelişebildiği düşünülmektedir (4). $\mathrm{Bu}$ dönemde yorgunluk, nefes darlığı, kas ve eklem ağrıları ve uyku bozuklukları sik görülen yakınmalardır (5). Covid 19 enfeksiyonunun akut döneminde hiponatremi sık görülen elektrolit bozukluklarındandır. Gerek tanı anında gerekse tedavi sürecinde hiponatremi görülebilmektedir (6). İnflamasyonun ciddiyetinde, Interlökin-6(IL6) artışında, solunum yetmezliğinin gelişmesinde ve yoğun bakıma gidişte hiponatreminin erken dönem bir belirteç olup olmadığı tartışılmaktadır (7). $\mathrm{Bu}$ olgu sunumunda, Covid 19 enfeksiyonu sonras1 semptomları tam olarak geçmemiş bir hastada gelişen ani başlangıçlı bulantı, kusma ve hiponatremi ayırıcı tanısı değerlendirilmiştir. Hastanın laboratuvar tetkikleri ilk başta uygunsuz antidiüretik hormon (ADH) salınımı olarak yorumlanmış, sonrasında ayrıcı tanısında adrenal bez değerlendirilmiş, adrenal yetmezlik ve hipofizer makroadenom tanısına ulaşılmıştır. Bu yazı; literatürde post covid erken dönemde hiponatreminin tartışıldığı ilk olgu sunumudur.

\section{Olgu Sunumu}

63 yaşında erkek hasta, 1 haftadır devam eden bulantı ve kusma şikayetiyle başvurdu. Bulantısının günde 3-4 kez, yediklerini içerir tarzda olduğu, iştahsızlık ve yorgunlukla birlikte seyrettiği öğrenildi. Özgeçmişinde hipotiroidi ve hipertansiyon tanıları mevcuttu. Başvurusundan 1 ay önce Covid 19 enfeksiyonu nedeniyle hastaneye yatış öyküsü vard1. Taburcu olduktan sonra kas ağrısı ve halsizlik yakınmalarının devam ettiği öğrenildi. Acil servise başvurduğunda kan basınc1:134/74mmHg, nabız:65atım/dk, solunum say1s1: 20/dk SpO2:98 idi. Fizik muayanesinde; genel durum orta, bilinci açık olup uykuya meyilli, deri turgor tonusu azalmış ve mukozalar kuruydu. Şiddetli hiponatremi ile saptanan hastanın nörolojik muayenesi detaylı değerlendirilmiş olup bilincin uykuya meyilli olması dışında patoloji saptanmadi. Diğer sistem muayenelerinde de patoloji saptanmadi. İlk başvuru tetkiklerinde hemoglobin:12,2 gr/dl, beyaz küre sayısı: 4310 /ul absolü nötrofil sayısı(ANS):2530 /ul, absolü lenfosit sayısi(ALS): 1310 /ul, platelet: $203000 / \mathrm{ul}$, glukoz: $163 \mathrm{mg} / \mathrm{dl}$, sodyum:115 meq/l, potasyum: 3,59 meq/l, kalsiyum:8,06 meq/l, albumin:3,64 g/dl, kreatin:0,57 mg /dl, kan üre azotu: $\quad 4,6 \mathrm{mg} \quad / \mathrm{dl}$, aspartataminotransferaz(AST):23 u/l, alaninamiotransferaz (ALT):10u/l, gamaglutamiltransferaz (GGT):12u/l, laktatdehidrogenaz (LDH):166u/1, alkalenfosfotaz(ALP):39u/1, c-reaktif protein (CRP):7,9 mg /1 olarak görüldü. Tam idrar tetkikinde $\mathrm{pH}: 6$ dansite:1014, protein: negatif, glukoz: negatif, keton: +1 , bilirubin:negatif, $w b c<1, r b c: 2$, spot idrar sodyum: $87 \mathrm{mEq} / \mathrm{L}$, serum osmolalitesi $240 \mathrm{mOsm} / \mathrm{kg}$ olarak saptand. İdrar osmolalitesi teknik nedenlerden bakılamadi. Hastanın ilk değerlendirmesinin ardından hipovolemik hiponatremi düşünülerek İç Hastalıkları servisine yatışı verildi. İndapamid tedavisi kesildi. Öncelikle hastaya sodyum açığı hesaplanarak $100 \mathrm{cc} /$ saatten izotonik sodyum klorür infüzyonu başland. Yakın hemodinamik takip ve $\mathrm{Na}$ takibi yapıldı. Dehidratasyonu düzelen, bulantı ve kusmas1 kesilen hasta övolemik haldeyken spot idrar sodyumu: $45 \mathrm{mEq} / \mathrm{L}$ olarak serum osmolalitesi $250 \mathrm{mOsm} / \mathrm{kg}$ olarak sonuçland. $\mathrm{Bu}$ süreçte uygunsuz ADH salınımı ön planda düşünüldüğünden günlük sivı alımı kısıtlı takip edilip, oral tuz tedavisi başland. Uygunsuz ADH kliniğini açıklayabilecek 
diğer nedenler değerlendirildi. Hastanın Covid enfeksiyonunu yakın dönemde geçirmiş olması; halsizlik, iştahsızlık şikayetleri, eklenen bulantı ve kusma yakınması nedeniyle bazal kortizolü çalışıldı. Sabah 08:00 kortizolü: 9,3 ug / dL, tekrarı 2 gün sonra 9,63 ug /dL olarak ölçüldü ACTH:26,5pg/mLve ACTH uyarı testi planland. Eş zamanlı kranial ve hipofizer görüntüleme istendi. ACTH uyarısına cevap yetersiz olarak saptandi. Hipofiz MR'da sellayı sağ lateral kısmı haricinde tama yakın dolduran, suprasellar sisterne kadar uzanan $2 \mathrm{x}$ $1,7 \mathrm{~cm}$ boyutta makroadenom tespit edildi. Hipofizde saptanan kitle ile ilişkili istenen hormon tetkikleri düşük kortizol düzeyi dışında normal sınırlarda saptandı. Hasta endokrinoloji ve beyin cerrahisi bölümlerine yönlendirildi. Hastanın operasyonuna karar verildi.

\section{Tartışma ve Sonuç}

Hiponatremi, yatan hastalarda en s1k karşılaşılan elektrolit bozukluğudur. Klinik belirtileri büyük ölçüde gelişme hızına bağlıdır ve akut, semptomatik hiponatremi ciddi bir klinik durumdur. Patogenezindeki temel mekanizmalardan birinin ADH'in non ozmotik ve uygunsuz salgilanması olduğu saptanmıştır (8). Olgumuzun; Covid 19 enfeksiyonu sonrası birinci ayında halsizlik ve kas ağrısı yakınmaları sürerken bulantı ve kusma şikayeti başlamış ve yapılan tetkiklerinde hiponatremi tespit edilmiştir. Hastanın başlangıç verileri uygunsuz ADH sendromuna bağlı hiponatremi olarak değerlendirilmiştir. Ayırıcı tanısında adrenal ve tiroid bezi değerlendirilen olguda adrenal yetmezlik ile uyumlu sonuçlara ulaşılmıştır. Literatürde Covid 19 hastalarının \%12-30 arasında değişen oranda hiponatremi varlığ bildirilmiştir (9). Bu olgulardaki hiponatremi gelişiminde; sıvı elektrolit kaybı, renal hasar, oral tuz alımındaki yetersizlik ve uygunsuz ADH sendromu önemli nedenler arasındadır. Covid- 19 enfeksiyonunun akut döneminde gelişen uygunsuz ADH sendromunda; viral enfeksiyonun kendisi, inflamasyon, IL-6 ve diğer inflamatuar sitokinlerin artmış sekresyonunun etkisinin olabileceği düşünülmüştür (6). IL-6; direk olarak serum osmolalitesinden bağımsız olarak ADH salınımını uyarabildiği gibi inflamatuar süreçte alveolar bazal membrandaki hasarlanma ile hipoksik pulmoner vazokonstrüksiyonu tetikleyerek $\mathrm{ADH}$ düzeyini artabilir (10). Literatürde ilk olarak Ho ve arkadaşları, yeni başlayan nöbetlerle kendini gösteren uygunsuz ADH salınımı ile ilişkili hiponatremi ve COVID-19 vakasını bildirdikten sonra benzer birlikteliğin tartış1lığg farklı olgu örnekleri sunulmuştur $(10,11)$ Hiponatremi, $\quad$ COVID-19 enfeksiyonunda en sik görülen elektrolit bozukluğu olduğu gibi kötü prognostik faktör olarak da tartışılmaktadır. Özellikle hastane yatışı olan ve yoğun bakım ihtiyacı gelişen hastalarda hiponatreminin mortalite için bağımsız bir risk faktörü olduğu bildirilmiştir (12). Berni ve ark.'ları çalışmalarında sodyum düzeyindeki düşüşün IL-6 düzeyindeki artıştan önce gösterilebileceğini ve bunun respiratuar performasın göstergesi olarak da kullanabileceğini belirtmişlerdir. $\mathrm{Bu}$ durum ayn1 zamanda antisitokin tedavinin zamanlaması konusunda da yol gösterici olabilmesi açısından önemlidir (7). Olgumuz Covid 19 enfeksiyonunu hastanede yatırilarak ve orta şiddette Covid 19 pnömonisi ile geçirmiştir. Hastaneden çıtıktan sonra da iştahsızlık, bulantı ve konstitüsyonel yakınmaları devam etmiş sonrasında da bulant1, kusma ve takip eden dönemde hiponatremi saptanmıştır. Hastane çıkış verilerinde de sodyum düzeyi normalin alt sınırında görülmektedir. Merino ve ark.'ları 59 yaşında kuru öksürük, nefes darlığı, karın ağrısı, bulantı ve baş ağrısı ile başvuran Covid 19 tanısı almış ve akut enfeksiyon tedavisi süren bir olguda, hiponatremi, hipokortizolizm ve hipofizer makroadenom saptamıştır (13). Hasta takibi sürerken uygunsuz ADH salınımına neden olabilecek durumlar eş zamanlı araştırıldığında bazal kortizol değeri düşük saptandı uyarı testlerine yanıt alınamadı, adrenal yetmezlik ve hipofiz görüntülemesi sonucunda da hipofizer makroadenom tespit edilmiştir. Klinikte hiponatremi etyolojisini araştırdığımız tüm hastalar adrenal yetmezlik açısından da incelenmelidir. $\mathrm{Bu}$ olguda hastanın uzamış bulantı, kusmaları oluşu ve hiponatreminin düzelmesine rağmen yakınmalarının tamamen geçmemesi ve bazal kortizol değerinin düşük oluşu adrenal yetmezlik açısından uyarı testi 
yapılmasin1 gerektirdi. SARS-COV-2 enfeksiyonu sirasinda ACE-2 reseptörü bulunan her organ ve sistemde etkilenme olabilir, nitekim adrenal bezde hasarlanma ve buna bağlı adrenal yetmezlik vakaları bildirilmiştir. Hipotalamik hipofizer aksta da fonksiyonel bozukluk gelişebilir (14). Burada hem direkt sitopatik etki hem de viral antikorların ACTH üzerine baskılayıcı etkisine bağl1 kortizol yetersizliği gelişebilir. Hashim ve ark.' 'ları olgu sunumlarında bulantı yakınması ile başvuran, Covid 19 tanısı alan ve takipte adrenal yetmezlik tespit ettikleri 51 yaşındaki kadın hastayı tartışmışıır (15). Leow ve ark.'larının yaptıkları bir çalışmada da SARS enfeksiyonu sonrası 3 . ayda çalıșma grubundaki hastaların yaklaşık yarısında hipokortizolizm tespit ettiklerini ve bu durumun geri dönüşümlü hipofizit veya direkt olarak hipotalamik etki ile ilișkili olabileceğini vurgulamışlardır (16). Çin sağlık bakanlığı tarafından yapılan bir başka klinik çalışmada ise ciddi Covid-19 enfeksiyonu geçirenlerde ACTH değişikliği vurgulanmıştır (17).

Olgumuzda her ne kadar adrenal yetmezlik etyolojisinde hipofizer makroadenom tespit edilmiş olsa da hiponatreminin gelişmesinde ve hastanın semptomatik oluşunda yakın dönemde orta- ağır geçirdiği Covid 19 enfeksiyon sürecinin steroid dekompansasyon sürecine etkisi olabileceğini düşünmekteyiz. Gerek enfeksiyon sürecinde gerek ise post Covid-19 dönemde adrenal bez ve hipotalamik hipofizer aks ile ilişkili sorunlarla karşılaşılabileceği unutulmamalıdır. Deneyimlerimiz bize; Covid 19 enfeksiyonunu semptomatik, orta-ağır pnömoni ile atlatmış, steroid kullanımı ve hastane yatışı olan hastaların post covid polikliniklerde diğer sistemik muayenelerinin yanında sıvı elektrolit bozuklukları açısından da değerlendirilmesini ve gelişebilecek sorunlar açısından dikkatli olunmasının gerekli olabileceğini düşündürmektedir.

\section{KAYNAKLAR}

1. https://covid19.saglik.gov.tr/Eklenti/39551/0/co vid19rehberigenelbilgilerepidemiyolojivetanipd f.pdf

2. World Health Organization. Coronavirus disease (COVID-19) pandemic.

Online Erişim: https://www.who.int/ emergencies/diseases/novel-coronavirus-2019.

3. COVID-19 rapid guideline: managing the longterm effects of COVID-19. NICE guideline, 2020. https://www.nice.org.uk/guidance/ng188.

4. https://blogs.bmj.com/bmj/2020/12/09/confront ing-the-pathophysiology-of-long-covid/

5. https://www.cdc.gov/coronavirus/2019ncov/long-term-effects.html

6. Gheorghe G., Ilie M., Bungau S., Stoian AMP., Bacalbasa N., Diaconu CC. Is There a Relationship between COVID-19 and Hyponatremia? Medicina (Kaunas). 2021; 57: 55.

7. Berni A, Malandrino D, Parenti G, Maggi M, Poggesi L, Peri A. Hyponatremia, IL-6, and SARS-CoV-2 (COVID-19) infection: may all fit together? $J$ Endocrinol Invest. 2020;43:1137-39.

8. https://turkjnephrol.org/Content/files/sayilar/33 5/115-131.pdf.

9. Butt I., Sawlani V., Geberhiwot T. Prolonged confusional state as first manifestation of COVID-19. Ann Clin Transl Neurol. 2020;7:1450-52.
10. Yousaf Z., Al-Shokri SD., Al-soub H., F. H. Mohamed M. COVID-19-associated SIADH: a clue in the times of pandemic. Am J Physiol Endocrinol Metab. 2020;1: 318: E882-885.

11. Ho KS, Narasimhan B, Kumar A, Flynn E, Salonia J, El-Hachem K, Mathew JP. Syndrome of inappropriate antidiuretic hormone as the initial presentation of COVID19: A novel case report. Nefrologia. 2021;41:218-20.

12. De Carvalho H, Letellier $T$, Karakachoff $M$, Desvaux G, Caillon H, Papuchon E, BentoumiLoaec M, Benaouicha N, Canet E, Chapelet G, Le Turnier P, Montassier E, Rouhani A, Goffinet N, Figueres L. Hyponatremia is associated with poor outcome in COVID-19. $J$ Nephrol. 2021;34:991-98.

13. De La Flor Merino JC, Mola Reyes L, Linares Gravalos T, Roel Conde A, Rodeles Del Pozo M. An usual case of severe acute hyponatremia in patient with Covid 19 infection. Nefrologia (Engl Ed). 2020;40:356-58.

14. Sezer H., Deyneli O. COVID-19 ve Adrenal Hastalıkların Yönetimi. Endokrinoloji ve COVID-19. 1. Bask1. Ankara: Türkiye Klinikleri; 2020. p.5-11.

15. Hashim M., Athar S., Gaba WH. New onset adrenal insufficiency in a patient with COVID19. BMJ Case Rep. 2021 18;14: e237690.

16. Leow MK-S, Kwek DS-K, Ng AW-K, et al. Hypocortisolism in survivors of severe acute 
respiratory syndrome (SARS). Clin Endocrinol 2005; 63:197-202.

17. Chinese Clinical Trial Register. Wuhan (Hubei): Ministry of Health (China) Identifier ChiCTR2000030115. A clinical research for the changes of blood cortisol ACTH level and adrenal morphology in blood cortisol to guide the application of individualized hormone in severe novel coronavirus pneumonia (COVID-

19) patients, 2020.

@Copyright 2022 by Osmangazi Tıp Dergisi - Available online at tip.ogu.edu.tr @Telif Hakkı 2022 ESOGÜ Tıp Fakültesi - Makale metnine dergipark.org.tr/otd web sayfasından ulaşılabilir. 